LWSA

PAPER - OPEN ACCESS

\title{
Analisis Faktor-Faktor yang Mempengaruhi Pengeluaran Konsumsi Pangan Rumah Tangga (Studi Kasus : Desa Karang Gading, Kecamatan Secanggang, Kabupaten Langkat)
}

\author{
Author : Rizka Faradina \\ DOI $\quad: 10.32734 /$ lwsa.v1i1.178 \\ Electronic ISSN : :2654-7058 \\ Print ISSN :2654-7066
}

Volume 1 Issue 1 - 2018 TALENTA Conference Series: Local Wisdom, Social and Arts

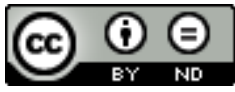

This work is licensed under a Creative Commons Attribution-NoDerivatives 4.0 International License.

Published under licence by TALENTA Publisher, Universitas Sumatera Utara
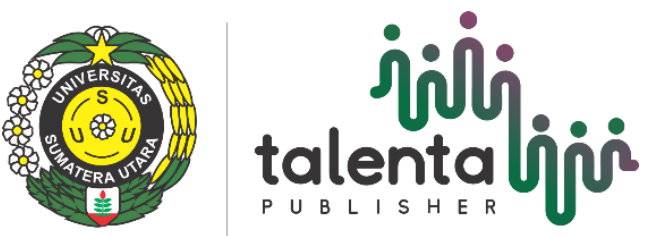


\title{
Analisis Faktor-Faktor yang Mempengaruhi Pengeluaran Konsumsi Pangan Rumah Tangga (Studi Kasus : Desa Karang Gading, Kecamatan Secanggang, Kabupaten Langkat)
}

\author{
Rizka Faradina ${ }^{\mathrm{a}}$, Iskandarini ${ }^{\mathrm{a}}$, Satia Negara Lubis ${ }^{\mathrm{a}}$ \\ ${ }^{a}$ Fakultas Pertanian, Program Studi Agribisnis, Universitas Sumatera Utara ,Indonesia \\ rizkha.faradhina@gmail.com,rini_soetadi@yahoo.com,satia_waspada@yahoo.com
}

\begin{abstract}
Abstrak
Penelitian ini bertujuan untuk menganalisis pengaruh faktor tingkat pendapatan rumah tangga, tingkat pendidikan ibu rumah tangga, jumlah anggota rumah tangga, dan umur perkawinan terhadap pengeluaran pangan rumah tangga didaerah penelitian dan untuk menganalisis tingkat ketahanan pangan rumah tangga dilihat dari presentase pengeluaran untuk pangan pada rumah tangga di daerah penelitian. Metode penentuan daerah yang digunakan dalam penelitian ini adalah purposive dengan pertimbangan bahwa Desa Karang Gading merupakan Desa dengan jumlah rumah tangga terbesar yang ada di kecamatan Secanggang. Metode penentuan jumlah sampel yang digunakan dalam penelitian ini adalah metode slovin. Sedangkan metode analisis data yang digunakan adalah menggunakan analisis regresi linier berganda dan metode kuantitatif dengan melihat persentase pengeluaran pangan. Dari hasil penelitian, diperoleh bahwa secara serempak keempat faktor tersebut berpengaruh nyata terhadap pengeluaran konsumsi pangan rumah tangga. Secara parsial faktor pendapatan rumah tangga dan jumlah anggota keluarga berpengaruh nyata terhadap pengeluaran konsumsi pangan sedangkan faktor tingkat pendidikan ibu rumah tangga dan umur perkawinan tidak berpengaruh nyata. Serta rumah tangga yang ada di Desa Karang Gading termasuk rumah tangga tidak tahan pangan karena sebanyak 65\% sampel rumah tangga memiliki persentase pengeluaran pangan yang tinggi.
\end{abstract}

Kata Kunci: rumah tangga; pengeluaran pangan; pangsa pengeluaran pangan

\section{Latar belakang}

Pangan merupakan kebutuhan manusia yang paling azasi, sehingga ketersediaan pangan bagi masyarakat harus selalu terjamin. Manusia dengan segala kemampuannya selalu berusaha untuk mencukupi kebutuhannya dengan berbagai cara. Dalam perkembangan peradaban masyarakat untuk memenuhi kualitas hidup yang maju, mandiri, dalam suasana tenteram serta sejahtera lahir dan bathin, semakin dituntut penyediaan pangan yang cukup, berkualitas, aman, dan merata. Oleh karena itu, kecukupan pangan bagi suatu bangsa merupakan hal yang sangat strategis untuk mewujudkan pembangunan sumber daya manusia yang sehat, aktif, dan produktif (BKP, 2010).

Ketahanan pangan di suatu wilayah dan masyarakat dicerminkan oleh kondisi terpenuhinya kebutuhan pangan rumah tangga yang tercermin dari tersedianya pangan yang cukup, baik jumlah maupun mutunya, terdistribusi dengan harga terjangkau dan aman dikonsumsi untuk dapat melakukan aktifitas sehari-hari sepanjang waktu. (Rachman, 2005). 
Secara nasional, kewajiban mewujudkan ketahanan pangan tertuang secara eksplisit dalam UU Nomor 7 Tahun 1996 tentang Pangan, dimana dalam konsep ketahanan pangan telah termuat aspek keamanan, mutu dan keragaman sebagai kondisi yang harus dipenuhi dalam kebutuhan pangan penduduk secara cukup dan merata serta terjangkau. Kondisi ketahanan pangan yang diperlukan juga mencakup persyaratan bagi kehidupan sehat. Definisi ketahanan pangan sebagaimana yang termuat dalam Undang-Undang RI Nomor 7 tahun 1996 tentang Pangan adalah sebagai berikut : "Ketahanan pangan adalah kondisi terpenuhinya pangan bagi rumah tangga yang tercermin dari tersedianya pangan yang cukup, baik jumlah maupun mutunya, aman, merata terjangkau" (Sumarmi, 2010).

Banyak indikator lain yang digunakan untuk melihat ketahanan pangan, namun beberapa diantaranya sulit diukur. Indikator yang baik mempunyai ciri: cukup sederhana untuk pengumpulan dan penafsirannya, objektif dan dapat diukur dengan angka, dan responsif terhadap perubahan-perubahan akibat adanya program (Suhardjo, 1989). Seharusnya indikator ketahanan pangan dapat mempresentasikan jumlah dan mutu pangan yang dikonsumsi sesuai norma gizi. Walaupun program peningkatan produksi pangan menunjukkan keberhasilan namun masih sering dijumpai isu ketidaktahanan pangan. Ini berarti peningkatan produksi pangan belum cukup dijadikan indikator ketahanan pangan. Pangsa pengeluran pangan merupakan salah satu indikator ketahanan pangan, makin besar pangsa pengeluaran untuk pangan berarti ketahanan pengeluaran pengan penduduknya semakin kecil, demikian sebaliknya (Deaton dan Muellbauer, 1980).

\section{Metode penelitian}

\subsection{Metode penentuan daerah penelitian}

Metode Penentuan daerah penelitian dilakukan secara Purposive (sengaja), yaitu di Desa Karang Gading, Kecamatan Secanggang, Kabupaten Langkat, Provinsi Sumatera Utara. Pemilihan daerah ini dikarenakan daerah ini merupakan daerah yang paling banyak memiliki rumah tangga.

Tabel 1. Banyaknya penduduk dan rumah tangga dirinci menurut desa/kelurahan.

\begin{tabular}{lcc}
\hline \multicolumn{1}{c}{ Desa/kelurahan } & Penduduk & Jumlah rumah tangga \\
\hline Kepala Sungai & 5627 & 1384 \\
Perkotaan & 2122 & 522 \\
Teluk & 4977 & 1225 \\
Cinta Raja & 1088 & 268 \\
Telaga Jernih & 5327 & 1310 \\
Karang Gading & 6412 & 1578 \\
Kuala Besar & 1240 & 305 \\
Selotong & 4503 & 1109 \\
Secanggang & 6247 & 1538 \\
Tanjung Ibus & 4915 & 1210 \\
Hinai Kiri & 5091 & 1253 \\
Kebun Kelapa & 2708 & 667 \\
Sungai Ular & 2522 & 621 \\
Jaring halus & 3035 & 747 \\
Karang Anyar & 4845 & 1193 \\
Pantai Gading & 3754 & 923 \\
Suka Mulia & 3479 & 856 \\
\hline & 67892 & 16709 \\
\hline
\end{tabular}

Sumber: Kecamatan Secanggang Dalam Angka 2015

Dengan pertimbangan 1.578 rumah tangga yang terdapat di daerah penelitian ini memungkinkan banyak variasi komsumsi pangan antar rumah tangga.

\subsection{Metode penentuan sampel}

Metode Penentuan Sampel Metode pengambilan sampel dilakukan dengan metode Slovin dengan persamaan sebagai berikut : 


$$
\mathrm{n}=\frac{\mathrm{N}}{1+\mathrm{Ne}^{2}}
$$

dimana:

$\mathrm{n}=$ jumlah sampel

$\mathrm{N}=$ jumlah populasi

$\mathrm{e}=$ batas toleransi kesalahan (error tolerance)

Jumlah masyarakat menurut data kependudukan Desa Karang Gading adalah 1.578 rumah tangga. Dengan batas toleransi 10\% maka jumlah sampel yang diambil dari keseluruhan jumlah populasi adalah sebanyak 94 sampel rumah tangga. Metode yang digunakan dalam pengambilan sampel adalah Random Sampling Method dimana semua unsur dari populasi mempunyai kesempatan yang sama untuk dipilih sebagai anggota sampel dan pengambilan sampel dilakukan secara acak tanpa memperhatikan strata yang ada didalam populasi.

\subsection{Metode pengumpulan data}

Data yang dikumpulkan dalam penelitian ini adalah data primer dan data sekonder. Data primer diperoleh dari wawancara dan hasil pengumpulan data secara langsung kepada tiap rumah tangga di Desa Karang Gading, Kecamatan Secanggang, Kabupaten Langkat yang dijadikan sampel dengan memakai kuesioner.

Data sekunder merupakan data pelengkap yang diperoleh dari Kantor Kepala Desa Karang Gading, Badan Pusat Statistik, serta literatur yang berkaitan dengan judul.

\subsection{Metode analisis data}

Untuk identifikasi masalah 1, diuji dengan menggunakan analisis regresi linier berganda dimana sebuah variabel terikat (Y) dihubungkan dengan dua atau lebih variabel bebas (X). Untuk mengetahui variabel bebas (pendapatan rumah tangga, tingkat pendidikan ibu rumah tangga, jumlah anggota keluarga, lamanya berumah tangga/umur perkawinan) terhadap variabel terikat yakni pengeluaran untuk konsumsi rumah tangga.

Model regresi linear berganda yang digunakan :

$$
\dot{Y}=a+b 1 X 1+b 2 X 2+b 3 X 3+b 4 X 4+\mu
$$

dimana:

$\hat{Y}=$ pengeluaran rumah tangga (Rp/bulan)

$\mathrm{a}=$ intercept atau konstanta

b1,b2,b3,b4 = koefisien regresi

$\mathrm{X} 1$ = pendapatan rumah tangga $(\mathrm{Rp} / \mathrm{bulan})$

$\mathrm{X} 2$ = tingkat pendidik ibu rumah tangga (tahun)

X3 = jumlah anggota keluarga (jiwa)

X4 = lamanya berumah tangga (tahun)

$\mu=$ error term (koefisien error)

Uji kesesuaian model (test of goodness of fit)

1. Koefisien determinasi $\left(\mathrm{R}^{2}\right)$

Koefisien determinasi $\mathrm{R}^{2}$ merupakan suatu nilai statistik yag dihitung dari data sampel. Koefisien ini menunjukkan presentase variasi seluruh variabel terikat yang dapat dijelaskan oleh perubahan variable bebas. Koefisien ini merupakan suatu ukuran sejauh mana variabel bebas dapat mengubah variabel terikat dalam suatu hubungan.

Nilai koefisien determinasi $\mathrm{R}^{2}$ berkisar antara $0<\mathrm{R}^{2}<1$, dengan kriteria pengujiannya adalah sebagai berikut:

- Jika nilai $\mathrm{R}^{2}$ semakin tinggi (mendekati 1) menunjukkan variabel bebas mampu menjelaskan keragaman dari variabel terikat.

- Jika nilai $\mathrm{R}^{2}$ kecil menunjukkan variabel bebas kurang mampu menjelaskan keragamn dari variabel terikat. 


\section{Uji F}

Uji F digunakan untuk menguji apakah semua variabel bebas yang dimasukkan kedalam model secara serempak berpengaruh nyata terhadap variabel terikat. Uji $\mathrm{F}$ dimaksudkan untuk mengetahui tingkat signifikansi statistik koefisien regresi secara serempak. Tarif signifikansi $(\alpha)$ yang digunakan dalam ilmu sosial adalah 0,05 .

kriteria uji sebagai berikut :

Jika Fhitung $\leqslant$ Ftabel atau jika signifikansi F $>$ a : maka terima H0 tolak H1

Jika Fhitung $>$ Ftabel atau jika signifikansi $\mathrm{F}<\alpha$ : maka tolak H0 terima H1

Hipotesis :

$\mathrm{H} 0$ = Tingkat pendapatan rumah tangga, tingkat pendidikan ibu, jumlah anggota rumah tangga dan umur perkawinan secara serempak tidak berpengaruh nyata terhadap pengeluaran konsumsi pangan didaerah penelitian

$\mathrm{H} 1$ = Tingkat pendapatan rumah tangga, tingkat pendidikan ibu, jumlah anggota rumah tangga dan umur perkawinan secara serempak berpengaruh nyata terhadap pengeluaran konsumsi pangan didaerah penelitian

\section{Uji T}

Digunakan untuk menguji apakah semua variabel bebas yang dimasukkan kedalam model secara serempak berpengaruh nyata terhadap variabel terikat. Uji F dimaksudkan untuk mengetahui tingkat signifikansi statistik koefisien regresi secara serempak. Tarif signifikansi $(\alpha)$ yang digunakan dalam ilmu sosial adalah 0,05 .

kriteria uji sebagai berikut :

Jika thitung $\leqslant$ ttabel atau jika signifikansi $\mathrm{F}>a:$ maka terima $\mathrm{H} 0$ tolak $\mathrm{H} 1$

Jika thitung $>$ ttabel atau jika signifikansi $\mathrm{F}<\alpha$ : maka terima $\mathrm{H} 1$ tolak $\mathrm{H} 0$

Hipotesis :

$\mathrm{H} 0$ = Tingkat pendapatan rumah tangga, tingkat pendidikan ibu, jumlah anggota rumah tangga dan umur perkawinan secara parsial tidak berpengaruh nyata terhadap pengeluaran konsumsi pangan didaerah penelitian.

H1 = Tingkat pendapatan rumah tangga, tingkat pendidikan ibu, jumlah anggota rumah tangga dan umur perkawinan secara serempak berpengaruh nyata terhadap pengeluaran konsumsi pangan didaerah penelitian.

Uji asumsi klasik

Uji asumsi klasik adalah persyaratan statistik yang harus dipenuhi pada analisis regresi linier berganda yang berbasis Ordinary Least Square (OLS). Pada prinsipnya model regresi linier yang dibangun sebaiknya tidak boleh menyimpang dari asumsi BLUE (Best, Linier, Unbiased, dan Estimator). Ada tiga uji asumsi klasik yang akan digunakan dalam penelitian ini antara lain uji multikolineritas, heterokedastisitas, dan normalitas.

Untuk Identifikasi Masalah 2, dianalisis dengan metode kuantitatif, yaitu dengan melihat besar pangsa atau persentase pengeluaran pangan terhadap total pengeluaran rumah tangga di daerah penelitian, dan dihitung dengan menggunakan rumus sebagai berikut :

$\mathrm{PF}=\frac{\mathrm{PP}}{\mathrm{PP}} \times 100 \%$

$$
\begin{aligned}
& \text { Dimana : } \\
& \mathrm{PF}=\text { Pangsa atau persentase pengeluaran pangan }(\%) \\
& \mathrm{PP}=\text { Pengeluaran untuk pangan rumah tangga }(\mathrm{Rp} / \mathrm{Bulan}) \\
& \mathrm{TP}=\text { Total pengeluaran rumah tangga (Rp/Bulan). }
\end{aligned}
$$

Apabila menggunakan indikator ekonomi, dengan kriteria apabila pangsa atau persentase pengeluaran pangan rendah $(\leqslant 60 \%$ pengeluaran total) maka kelompok rumah tangga tersebut merupakan rumah tangga tahan pangan. Sementara itu apabila pangsa atau persentase pengeluaran pangan tinggi ( $>60 \%$ pengeluaran total) maka kelompok rumah tangga tersebut merupakan rumah tangga rawan pangan. teori engel misalnya, menyebutkan bahwa semkain tinggi pendapatan maka proporsi pengeluaran untuk makanan sangat kecil (Rachman 2005). 


\subsection{Defenisi dan Batasan operasional}

Untuk menghindari kesalah pahaman dan kekeliruan dalam penelitian ini, maka dibuat defenisi dan batasan operasional sebagai berikut :

\subsubsection{Defenisi}

- Pangan adalah segala sesuatu yang berasal dari sumber daya hayati dan air, baik yang diolah maupun tidak diolah, yang diperuntukkan sebagai makanan dan minuman bagi konsumsi manusia termasuk bahan tambahan pangan, bahan baku pangan, dan bahan lain yang digunakan dalam proses penyiapan, pengolahan, dan atau pembuatan makanan dan minuman.

- Rumah Tangga adalah seorang/ sekelompok orang yang mendiami sebagian atau seluruh bangunan fisik atau sensus, dan biasanya makan bersama dari satu dapur. Yang dimaksud dengan makan dari satu dapur adalah mengurus kebutuhan sehari- hari bersama menjadi satu.

- Total Pengeluaran Rumah Tangga adalah keselurahan pengeluaran baik pangan dan nonpangan yang dikeluarkan oleh rumah tangga untuk memenuhi kebutuhan mereka, yang dinyatakan dalam uang (rupiah) pada periode waktu satu bulan.

- Pengeluaran Pangan Rumah Tangga adalah jumlah pendapatan rumah tangga yang dialokasikan untuk kebutuhan pangan yang dibeli oleh rumah tangga, yang yang dinyatakan dalam uang (rupiah) pada periode waktu satu bulan.

- Pengeluaran Nonpangan Rumah Tangga adalah jumlah pendapatan rumah tangga yang dialokasikan untuk kebutuhan nonpangan (pakaian, perumahan, pendidikan, transportasi, kesehatan dan iuran yang dinyatakan dalam uang (rupiah) pada periode waktu satu bulan.

- Pendapatan Rumah Tangga adalah jumlah seluruh pendapatan yang dihasilkan oleh kepala rumah tangga dan ibu rumah tangga yang digunakan untuk memenuhi kebutuhan hidup baik pangan maupun non pangan yang dinyatakan dalam uang (rupiah) pada periode waktu satu bulan.

- Tingkat pendidikan ibu rumah tangga adalah tingkat pendidikan formal terakhir yang ditempuh oleh ibu rumah tangga.

- Jumlah anggota rumah tangga adalah semua orang yang biasanya bertempat tinggal di suatu rumah tangga, yang terdiri dari ayah, ibu, anak dan anggota lainnya yang masih menjadi tanggungan kepala rumah tangga, yang dinyatakan dalam satuan jiwa.

- Lamanya berumah tangga/ umur perkawinan adalah umur suatu rumah tangga tersebut mulai saat terbentuk (menikah) hingga pada saat sekarang ini, yang dinyatakan dalam satuan tahun.

- Pangsa pengeluaran pangan adalah rasio pengeluaran pangan terhadap total pengeluaran rumah tangga

- Tahan pangan adalah rumah tangga yang pangsa pengeluaran pangan nya rendah $\leqslant 60 \%$.

- Tidak Tahan Pangan adalah rumah tangga yang pangsa pengeluaran pangannya tinggi $>60 \%$.

\subsubsection{Batasan operasional}

- Daerah Penelitian di Desa Karang Gading, Kecamatan Secanggang, Kecamatan Secanggang, Kabupaten Langkat.

- Sampel Penelitian adalah rumah tangga yang tinggal di daerah penelitian

- Waktu Penelitian 2016.

\section{Hasil penelitian dan pembahasan}

\subsection{Analisis Faktor- Faktor yang Mempengaruhi Pengeluaran Pangan Rumah Tangga di Desa Karang Gading Kecamatan Secanggang Kabupaten Langkat}

Faktor - faktor yang mempengaruhi pengeluaran pangan rumah tangga di Desa Karang Gading Kecamatan Secanggang Kabupaten Langkat diuji dengan menggunakan metode analisis regresi linier berganda, yaitu regresi linier dimana sebuah variabel terikat (variabel Y) dihubungkan dengan dua atau lebih variabel bebas (variabel X).

Di dalam penelitian ini yang digunakan sebagai variabel terikat (variabel Y) adalah pengeluaran pangan rumah tangga ( $\mathrm{Rp} / \mathrm{Bulan}$ ) dan sebagai variabel bebas (variabel $\mathrm{X}$ ) adalah: pendapatan rumah tangga (X1), tingkat pendidikan ibu rumah tangga (X2), jumlah anggota rumah tangga (X3), dan lamanya berumah tangga/ umur perkawinan (X4). 
Maka setelah dilakukan pengujian asumsi regresi linier berganda didapat hasil akhir dari estimasi faktor-faktor (pendapatan rumah tangga, pendidikan ibu rumah tangga, jumlah anggota keluarga dan lamanya berumah tangga/ umur perkawinan) yang mempengaruhi pengeluaran pangan rumah tangga di Desa Karang Gading Kecamatan Secanggang Kabupaten Langkat seperti pada tabel dibawah ini:

Tabel 2. Hasil analisis Regresi Faktor-Faktor yang Mmpengaruhi Pengeluaran Konsumsi Pangan Rumah Tangga di Desa Karang Gading Kecamatan Secanggang Kabupaten Langkat..

\begin{tabular}{llll}
\hline No. & Variabel & Koefisien regresi & Sieg. \\
\hline & (Constant) & 309368,78 & .000 \\
1 & Pendapa rumah tangga & 0,049 & .000 \\
2 & Tingkat Pendidikan ibu & $-1039,030$ & .529 \\
3 & Jumlah anggota keluarga & 74498,548 & .000 \\
4 & Umur perkawinan & $-345,060$ & .462 \\
\hline
\end{tabular}

Sumber: Lampiran 6, 2016

Dari Tabel 2 diperoleh persamaan:

$$
Y=309368,778+0,049 X 1-1039.030 X 2+74498,548 X 3-345,060 X 4+\mu
$$

Dimana :

$\mathrm{Y}=$ Pengeluaran Pangan Rumah Tangga (Rp/Bulan)

X1 = Pendapatan Rumah Tangga (Rp/Bulan)

$\mathrm{X} 2$ = Tingkat Pendidikan Ibu Rumah Tangga (tahun)

X3 = Jumlah Anggota Rumah Tangga (jiwa)

X4 = Lamanya berumah tangga/ umur perkawinan (tahun)

$\mu=$ koefisien error

Pada model regresi diatas, nilai konstanta tercantum sebesar 309.368 yang menunjukkan bahwa jika variabel bebas dalam model diasumsikan sama dengan nol, maka pengeluaran untuk konsumsi pangan rumah tangga di Desa Karang Gading, Kecamatan Secanggang, Kabupaten Langkat sebesar Rp. 309.368 perbulannya.

Untuk melihat nilai R-square dari faktor-faktor yang mempengaruhi pengeluaran konsumsi pangan pada rumah tangga di Desa Karang Gading Kecamatan Secanggang Kabupaten Langkat disajikan pada hasil regresi dibawah ini :

\begin{tabular}{lllll}
\multicolumn{5}{c}{ Model summary $^{a}$} \\
\hline Model & $R$ & R square & Adjusted $R$ square & Std. error of the stimate \\
\hline 1 & $.946^{\mathrm{a}}$ & .892 & .887 & 31493.489
\end{tabular}

a. Predictors: (Constant), Umur Perkawinan, Pendapatan, Jumlah Anggota Keluarga, Tingkat Pendidikan Ibu

b. Dependent Variable: Pengeluaran Pangan Rumah Tangga

Nilai koefisien determinasi yang diperoleh (R-square) adalah sebesar 0,892. Hal ini menunjukkan bahwa sebesar $89,2 \%$ variasi variabel terikat (pengeluaran pangan rumah tangga) dapat dijelaskan oleh variabel-variabel bebas (pendapatan rumah tangga, tingkat pendidikan ibu rumah tangga, jumlah anggota rumah tangga, dan lamanya berumah tangga/umur perkawinan), sedangkan sisanya 10,8\% dipengaruhi oleh variabel bebas lain yang tidak dimasukkan kedalam model. 
Dan untuk melihat nilai uji $\mathrm{F}$ dari faktor-faktor yang mempengaruhi pengeluaran konsumsi pangan pada rumah tangga di Desa Karang Gading Kecamatan Secanggang Kabupaten Langkat disajikan pada hasil regresi dibawah ini :

\begin{tabular}{lllllll}
\multicolumn{7}{c}{ Model summary $^{b}$} \\
\hline \multicolumn{1}{l}{ Model } & Sum of square & Df & Mean square & $F$ & Sig. \\
\hline 1 & Regression & $7.312 \mathrm{E} 11$ & 4 & $1.828 \mathrm{E} 11$ & 184.308 & $.000^{\mathrm{a}}$ \\
& Residual & $8.827 \mathrm{E} 10$ & 89 & $9.918 \mathrm{E} 8$ & & \\
& Total & $8.195 \mathrm{E} 11$ & 93 & & & \\
\end{tabular}

a. Predictors: (Constant), Umur Perkawinan, Pendapatan, Jumlah Anggota Keluarga, Tingkat Pendidikan Ibu

b. Dependent Variable: Pengeluaran Pangan Rumah Tangga

Berdasarkan uji F yang dilakukan, diperoleh nilai signifikansi Fhitung adalah sebesar $(0,000) \leqslant \alpha=0,005$. Hal ini berarti semua variabel bebas yang dimasukkan ke dalam model yakni pendapatan rumah tangga (X1), tingkat pendidikan ibu rumah tangga (X2), jumlah anggota rumah tangga (X3), dan lamanya berumah tangga/ umur perkawinan (X4) secara serempak memiliki pengaruh yang nyata/signifikansi terhadap variabel terikat yakni pengeluaran pangan rumah tangga (Y).

Secara lengkapnya, faktor- faktor yang mempengaruhi pengeluaran pangan rumah tangga di Desa Karang Gading Kecamatan Secanggang Kabupaten Langkat adalah:

\section{Pendapatan Rumah Tangga (Rp/ Bulan)}

Keluarga atau masyarakat yang berpenghasilan rendah, sebagian besar pendapatannya digunakan untuk mencukupi kebutuhan pangan. Akan tetapi, karena kebutuhan pangan relatif terbatas, maka mulai pada tingkat pendapatan tertentu pertambahan pendapatan akan dialokasikan lebih banyak untuk memenuhi kebutuhan nonpangan.

Pendapatan antara rumah tangga satu dengan rumah tangga lainnya di Desa Karang Gading berbeda sesuai dengan perolehan gaji/upah dari bapak/ibu yang berkerja di dalam satu rumah tangga. Di desa Karang Gading pekerjaan yang dimiliki setiap kepala rumah tangga bervariasi dari petani hingga TNI/Polri tapi didominasi oleh petani dan disusul oleh jenis pekerjaan peternak Dengan rata - rata pendapatan rumah tangga perbulannya sebesar Rp. 2.044.148/ bulan Sedangkan untuk pekerjaan ibu didominasi perkerjaan buruh harian lepas, untuk pekerjaan buruh harian lepas di Desa Karang Gading Kecamatan Secanggang Kabupaten Langkat merupakan pekerjaan harian lepas yang bekerja di ladang orang. Pendapatan perhari ibu-ibu yang bekerja sebagai buruh harian lepas di Desa Karang Gading Kecamatan Secanggang Kabupaten Langkat berkisar Rp. 20.000 - Rp. 35.000/hari.. Sehingga ada perbedaan mendasar ibu rumah tangga yang bekerja dengan ibu rumah tangga yang tidak bekerja dalam mengalokasikan pendapatan rumah tangga untuk memenuhi kebutuhan pangan itu sendiri dapat dilihat pada tabel 3 dibawah ini:

Tabel 3. . Rata-rata pengeluaran Konsumsi pangan bedasarkan Jenis Pekerjaan Ibu Rumah Tangga di Desa Karang Gading Kecamatan Secanggang Kabupaten Langkat.

\begin{tabular}{clll}
\hline No. & Jenis pekerjaan & Jumlah (rumah tangga) & Rata-rata pengeluaran pangan (Rp/bulan) \\
\hline 1 & Tidak Bekerja (IRT) & 54 & 729.111 \\
2 & Petani & 6 & 738.666 \\
3 & BHL & 20 & 735.105 \\
4 & PRT & 3 & 68.666 \\
5 & TPI & 3 & 76.700 \\
6 & Pedagang & 6 & 823.000 \\
7 & Penjahit & 2 & 763.500 \\
\hline & Jumlah & 94 & 3.934 .748 \\
\hline
\end{tabular}

Sumber: data diolah dari Lampiran 2 
Dari Tabel diatas terlihat jelas adanya perbedaan rata-rata pengeluaran untuk pangan rumah tangga pada ibu rumah tangga yang memiliki pekerjaan dibandingkan dengan ibu rumah tangga yang tidak bekerja. Dengan pekerjaan pedagang memiliki rata - rata pengeluaran rumah tangga paling tinggi sebesar Rp. 823.000/bulan,

Pendapatan yang diperoleh ibu di Desa Karang Gading Kecamatan Secanggang Kabupaten Langkat sangat membantu dalam memenuhi kebutuhan sehari-hari khususnya kebutuhan pangan, dimana kebutuhan pangan merupakan kebutuhan yang paling penting yang wajib terpenuhi dari kebutuhan lainnya.

Secara parsial, terdapat pengaruh yang nyata antara variabel pendapatan rumah tangga (X1) terhadap pengeluaran pangan rumah tangga di Desa Karang Gading dengan tingkat signifikansi $0,000 \leqslant \alpha=0,05$. Pengaruh pendapatan rumah tangga terhadap pengeluaran rumah tangga dapat ditunjukkan dari nilai koefisien regresi sebesar 0,049 . Hal ini berarti apabila terjadi peningkatan pendapatan rumah tangga sebesar Rp. 100.000,- per bulan maka akan meningkatkan pengeluaran pangan rumah tangga sebesar Rp. 4.900,- per bulannya.

Hal tersebut dapat dilihat pada rumah tangga di Desa Karang Gading dimana dengan bertambahnya pendapatan rumah tangga maka rata - rata pengeluaran pangan $\mathrm{j}$ uga ikut meningkat. Untuk lebih jelasnya, tingkat pendapatan rumah tangga sampel dan pengaruhnya denga pengeluaran pangan dapat dilihat pada Tabel 4 di bawah ini

Tabel 4. . Rata-rata pengeluaran pangan rumah di Desa Karang Gading Kecamatan Secanggang Kabupaten Langkat berdasarkan pendapatan rumah tangga

\begin{tabular}{llll}
\hline No. & Pendapatan rumah tangga (Rp/bulan) & $\begin{array}{l}\text { Rata-rata pendapatan rumah } \\
\text { tangga (Rp/bulan) }\end{array}$ & $\begin{array}{l}\text { Rata-rata pengeluaran rumah } \\
\text { tangga (Rp/bulan) }\end{array}$ \\
\hline 1 & < Rp. 999.000 & 752.500 & 580.500 \\
2 & Rp. $1.000 .000-$ Rp. .1999.000 & 1.642 .000 & 705.122 \\
3 & Rp. $2.000 .000-$ Rp. 2.999 .000 & 2.341 .000 & 718.103 \\
4 & $>$ Rp. 3.000 .000 & 3.445 .000 & 854.167 \\
\hline & Jumlah & 8.180 .500 & 2.857 .892 \\
\hline
\end{tabular}

Sumber: data diolah dari Lampiran 4

Dari tabel di atas, terlihat jelas adanya perbedaan rata - rata pengeluaran untuk pangan rumah tangga dengan berbagai tingkatan pendapatan, dimana semakin tinggi pendapatan rumah tangga tersebut, maka semakin tinggi pula alokasi pengeluaran mereka untuk mencukupi kebutuhan pangan. Artinya, pertambahan pendapatan rumah tangga tersebut hanya dapat digunakan untuk mencukupi kebutuhan pangan sehari-hari.:

Menurut penulis di daerah penelitian hal ini sangat wajar terjadi mengingat dengan bertambahnya pendapatan keluarga, Ibu rumah tangga cenderung untuk menambah atau mengubah menu makanan keluarga, baik dari segi kuantitas, kualitas, ataupun harga, misalnya sebelumnya ibu rumah tangga hanya menyediakan lauk sederhana seperti telur, tempe, tahu, maka ketika pendapatan keluarga naik, mereka cenderung untuk mengubah lauknya yang biasa menjadi ikan atau dagaing yang tetunya memiliki harga yang lebih mahal. Dan sesuai dengan Teori Keynes yang menyatakan, bahwa pengeluaran konsumsi akan meningkat dengan bertambahnya penghasilan.

Hal tersebut juga sesuai dengan pendapat Hardiansyah, 1985 yang mengatakan bahwa dengan meningkatnya pendapatan berarti memperbesar peluang untuk membeli pangan dengan kuantitas dan kualitas yang lebih baik. Sebaliknya penurunan pendapatan akan menyebabkan penurunan dalam hal kualitas dan kuantitas pangan yang dibeli. Dengan kata lain adanya hubungan yang positif antara pendapatan dengan konsumsi pangan itu sendiri. Dengan rata rata pengeluaran untuk konsumsi pangan di Desa Karang Gading Kecamatan Secanggang Kabupaten Langkat dapat dilihat pada tabel 5 dibawah ini

Table 5. Rata-rata pengeluaran konsumsi pangan rumah tangga di desa karang gading kecamatan secanggang kabupaten langkat

\begin{tabular}{llc}
\hline No. & Jenis pangan & Rata-rata pengeluaran (Rp/bulan \\
\hline 1 & Padi- padian (Beras) & 282.531 \\
2 & Umbi-umbian (Bawang, Ubi, Kentang dll) & 50.308 \\
3 & Pangan Hewani (Daging, Telur, Ikan) & 131.308
\end{tabular}




\begin{tabular}{llc}
4 & Minyak Goreng & 37.914 \\
5 & Kelapa, Kemiri & 7.085 \\
6 & Kacang-kacangan (K. Hijau, tahu, tempe, dll) & 27.021 \\
7 & Gula & 38.510 \\
8 & Sayur & 33.617 \\
9 & Buah & 1.489 \\
10 & Lain-lain (Bumbu makanan, kopi, teh dll) & 128.025 \\
\hline
\end{tabular}

Sumber: data diolah dari Lampiran 2

Pada tabel 5 dapat dilihat bahwa rumah tangga didaerah penelitian paling banyak mengalokasikan pendapatannya untuk membeli beras dengan rata-rata pengeluaran sebesar Rp.282.531/bulan, diikuti dengan mengalokasikan pendapatannya dalam memenuhi kebutuhan pangan hewani (daging, ikan, telur) dengan rata rata sebesar Rp. 131.308/bulan, dan paling sedikit pengeluaran konsumsi buah yang hanya sebesar Rp. 1.489/bulan dimana dikarenakan rumah tangga didaerah penelitian hampir tidak pernah membeli buah disebabkan bahwa setiap rumah ditanami pohon buah seperti mangga, rambutan, nangka dll. Sehingga mereka mengkonsumsi buah tanpa mengalokasikan pendapatannya untuk membeli buah.

\section{Tingkat Pendidikan Ibu Rumah Tangga (Tahun)}

Seorang ibu memiliki peranan besar dalam keluarga, dialah yang berbelanja pangan, mengatur menu keluarga, mendistribusikan makanan, mengatur keuangan dan pengeluaran, dan lain- lain. Tingkat pendidikan ibu rumah tangga, disamping merupakan modal utama dalam menunjang perekonomian keluarga juga berperan dalam penyusunan pola makan keluarga.

Dimana secara parsial, tidak terdapat pengaruh yang nyata/ siginifikan antara variabel tingkat pendidikan ibu rumah tangga (X2) terhadap pengeluaran pangan rumah tangga. Hal ini dapat dilihat dari diperolehnya tingkat signifikansi 0,529>a=0,05, sehingga kenaikan tingkat pendidikan ibu rumah tangga tidak akan berpengaruh terhadap pengeluaran pangan rumah tangga. Adapun rata - rata pengeluaran pangan rumah tangga berdasarkan tingkat pendidikan ibu rumah tangga dapat dilihat pada Tabel 6 di bawah ini.

Tabel 6. Rata-rata pengeluaran pangan rumah tangga di desa Karang Gading, kecamatan Secanggang, kabupaten Langkat berdasarkan tingkat pendidikan ibu rumah tangga.

\begin{tabular}{llll}
\hline No. & $\begin{array}{l}\text { Tingkat Pendidikan ibu rumah tangga } \\
\text { (tahun) }\end{array}$ & $\begin{array}{l}\text { Rata-rata pengeluaran pangan rumah tangga } \\
\text { (Rp/bulan) }\end{array}$ & $\begin{array}{l}\text { Jumlah rumah tangga } \\
\text { (jiwa) }\end{array}$ \\
\hline 1 & $0-6$ & 736.436 & 39 \\
2 & $7-9$ & 716.382 & 34 \\
3 & $10-12$ & 765.429 & 21 \\
\hline & Jumlah & 2.218 .247 & 94 \\
\hline
\end{tabular}

Sumber: data diolah dari Lampiran 4

Dari Tabel 6 di atas, diperoleh bahwa ternyata kenaikan tingkat pendidikan ibu rumah tangga tidak sepenuhnya memiliki pengaruh positif terhadap peningkatan pengeluaran pangan rumah tangga di Desa Karang Gading.

Ini menunjukkan adanya perbedaan yang mendasar dengan asumsi soekirman (2000) yang menyatakan bahwa tingkat pendidikan formal seorang ibu seringkali berhubungan positif dengan peningkatan pola konsumsi makanan rumah tangga yang pada akhirnya akan menambah pengeluaran untuk konsumsi pangan itu sendiri.

Menurut penulis hal ini diakibatkan karena pendidikan ibu di daerah penelitian sebanyak 39 ibu rumah tangga dengan tingkat pendidikan yang masih rendah, dan 21 ibu rumah tangga yang berpendidikan sampai lulus SMA. Dengan jumlah yang sedikit bila dibandingkan dengan ibu rumah tangga lainnya, maka mereka cenderung mengikuti kebiasaan masyarakat sekitar. Dimana hal ini sesuai dengan teori Duesenberry yang mengatakan bahwa selera rumah tangga atas barang konsumsi adalah interdependen. Artinya, pengeluaran konsumsi rumah tangga dipengeruhi oleh pengeluaran konsumsi yang dilakukan oleh masyarakat sekitarnya (tetangga) dengan kata lain faktor lingkungan berpengaruh besar terhadap pengeluaran konsumsi rumah tangga.

\section{Jumlah Anggota Rumah Tangga (Jiwa)}


Jumlah anggota rumah tangga akan mempengaruhi alokasi pengeluaran di rumah tangga tersebut. Semakin banyak jumlah anggota rumah tangga maka kebutuhan yang akan dikonsumsi akan semakin bervariasi karena masing- masing anggota rumah tangga memiliki selera yang berbeda- beda

Rumah tangga akan lebih mudah mencukupi kebutuhan pangannya apabila jumlah anggota di rumah tangga tersebut kecil.

Secara parsial, variabel jumlah anggota rumah tangga (X3) berpengaruh nyata terhadap pengeluaran pangan rumah tangga, dengan tingkat signifikansi $0,000 \leqslant \alpha=0,05$. Pengaruh jumlah anggota rumah tangga terhadap pengeluaran pangan rumah tangga dapat ditunjukkan oleh nilai koefisien regresi sebesar 74498,54. Koefisien antara anggota rumah tangga terhadap pengeluaran pangan rumah tangga menunjukkan hubungan yang positif. Artinya, setiap penambahan 1 jiwa anggota rumah tangga maka pengeluaran pangan rumah tangga akan bertambah sebesar Rp 74.499,- per bulannya dan sebaliknya.

Di Desa Karang Gading, Kecamatan Secanggang, Kabupaten Langkat rata - rata rumah tangga sampel memiliki 5 jiwa anggota rumah tangga. Untuk lebih jelasnya, jumlah anggota rumah tangga sampel dan hubungannya dengan pengeluaran rumah tangga dapat dilihat pada Tabel 7 di bawah ini.

Tabel 7. Rata-rata pengeluaran rumah tangga di desa Karang Gading, kecamatan Secanggang kabupaten Langkat berdasarkan jumlah anggota rumah tangga.

\begin{tabular}{llll}
\hline No. & Jumlah anggota keluarga (jiwa) & $\begin{array}{l}\text { Rata-rata pengeluaran pangan rumah tangga } \\
\text { (Rp/bulan) }\end{array}$ & Jumlah (rumah tangga) \\
\hline 1 & 3 & 568.600 & 10 \\
2 & 4 & 687.323 & 34 \\
3 & 5 & 779.216 & 37 \\
4 & 6 & 850.545 & 11 \\
5 & 7 & 933.500 & 2 \\
\hline & Jumlah & 3.819 .184 & 94 \\
\hline
\end{tabular}

Sumber: data diolah dari lampiran 4

Dari Tabel 7 di atas, jelas terlihat bahwa bertambahnya jumlah anggota rumah tangga, maka akan di ikuti dengan bertambahnya pengeluaran untuk konsumsi pangan rumah tangga. Atau dapat dikatakan adanya hubungan yang signifikan, dimana dengan bertambahnya jumlah anggota rumah tangga, akan diikuti juga dengan penambahan pengeluaran untuk konsumsi pangan rumah tangga.

Hal ini terjadi karena dengan bertambahnya jumlah anggota rumah tangga maka, rumah tangga tersebut sudah pasti memerlukan penambahan asupan pangan yang tentunya membutuhkan biaya. Dan hal ini sesuai dengan Teori Keynes, yang menyatakan ketika jumlah penduduk meningkat, maka jumlah barang yang diminta akan meningkat pula.

Melihat kondisi tersebut, penulis beranggapan bahwa perlunya kesadaran penduduk setempat akan arti pentingnya keluarga berencana untuk dapat mengendalikan jumlah anggota rumah tangga.

\section{Lamanya Berumah Tangga/ Umur Perkawinan (tahun)}

Alokasi pengeluaran rumah tangga di pengaruhi oleh lamanya berumah tangga/umur perkawinan. Setiap tingkatan keluarga, baik keluarga yang muda ataupun keluarga yang tua memiliki tingkat kebutuhan yang berbeda beda, baik pangan maupun non pangan. Suatu rumah tangga yang masih memiliki anak pada umur sekolah akan memiliki kebutuhan berupa perlengkapan sekolah, biaya uang sekolah, dan lain - lain yang tidak dimiliki oleh rumah tangga lain yang tidak memiliki anak pada umur sekolah.

Secara parsial, variabel lamanya berumah tangga/ umur perkawinan (X4) tidak memiliki pengaruh yang nyata/ signifikan terhadap pengeluaran pangan rumah tangga, dengan tingkat signifikansi sebesar $0,462>\alpha=0,05$. Artinya, variabel lamanya berumah tangga/ umur perkawinan tidak berpengaruh nyata terhadap pengeluaran rumah tangga. 
Untuk lebih jelasnya, rata - rata pengeluaran pangan rumah tangga di Desa Karang Gading, Kecamatan Secanggang, Kabupaten Langkat berdasarkan lamanya berumah tangga/ umur perkawinan dapat dilihat pada Tabel 8 .

Tabel 8. Rata-rata pengeluaran pangan rumah tangga di desa Karang Gading, kecamatan Secanggang kabupaten Langkat berdasarkan lamanya berumah tangga.

\begin{tabular}{llll}
\hline No. & $\begin{array}{l}\text { Lamanya berumah tangga/umur } \\
\text { perkawinan (tahun) }\end{array}$ & $\begin{array}{l}\text { Rata-rata pengeluaran pangan rumah tangga } \\
\text { (Rp/bulan) }\end{array}$ & Jumlah (rumah tangga) \\
\hline 1 & $6-10$ & 724.000 & 15 \\
2 & $11-15$ & 709.900 & 20 \\
3 & $16-20$ & 745.956 & 23 \\
4 & $21-25$ & 714.421 & 19 \\
5 & $26-30$ & 805.182 & 11 \\
6 & $31-25$ & 647.334 & 6 \\
\hline & Jumlah & & 94 \\
\hline
\end{tabular}

Sumber: data diolah dari lampiran 4

Dari Tabel 8 di atas, diperoleh bahwa ternyata lamanya berumah tangga/ umur perkawinan tidak sepenuhnya memiliki pengaruh yang positif terhadap pengeluaran pangan rumah tangga. Menurut penulis, hal ini disebabkan karena meskipun rumah tangga tersebut umurnya sudah cukup lama (bertahun- tahun), akan tetapi pendapatan rumah tangga tersebut masih tetap terbatas, sehingga rumah tangga tersebut hanya dapat mengalokasikan pendapatannya untuk kebutuhan pangan yang terbatas pula, baik keterbatasan dalam hal kuantitas, kualitas dan biaya.

Uji asumsi klasik dari faktor- faktor yang mempengaruhi pengeluaran pangan rumah tangga di Desa Karang Gading Kecamatan Secanggang Kabupaten Langkat dapat dijelaskan sebagai berikut.

Uji asumsi klasik

Untuk mendapatkan penaksir-penaksir yang bersifat BLUE (Best Linear Unbiased Estimator) dari penaksir linear OLS (Ordinary Least Square) maka harus memenuhi seluruh asumsi-asumsi klasik.

Uji asumsi klasik dari model regresi faktor-faktor sosial ekonomi masyarakat yang mempengaruhi pengeluaran pangan rumah tangga di Desa Karang Gading, Kecamatan Secanggang, Kabupaten Langkat.

1. Uji asumsi multikolinieritas

Multikolinieritas adalah suatu keadaan dimana variabel - variabel bebas saling berkorelasi. Persamaan regresi linier berganda yang baik adalah persamaan yang bebas dari adanya multikolinieritas antara variabel - variabel bebasnya. Ada atau tidaknya multikolinieritas pada model regresi terlihat dari tolerance dan VIF (Variance Inlaction Factor)

Kriteria nilai uji yang digunakan yakni:

1. Jika nilai VIF < 10, maka model tidak mengalami multikolinieritas

2. Jika nilai tolerance > 10 , maka model mengalami multikolinieritas

Hasil uji asumsi multikolinieritas untuk model faktor- faktor yang mempengaruhi pengeluaran pangan rumah tangga miskin di Desa Karang Gading Kecamatan Secanggang Kabupaten Langkat dapat dilihat pada Tabel di bawah ini : 


\begin{tabular}{llll}
\hline No & Variabel bebas & Collinearty & Statistic \\
\cline { 3 - 4 } & & Tolerance & VIF \\
\hline 1 & Pendapatan & 0.595 & 1.680 \\
2 & Tingkat Pendidikan Ibu & 0.722 & 1.384 \\
3 & Jumlah Anggota Keluarga & 0.723 & 1.384 \\
4 & Umur Perkawinan & 0.966 & 1.035 \\
\hline
\end{tabular}

Sumber: analisis lampiran 4

Hasil uji asumsi multikolinieritas untuk model pengeluaran pangan rumah tangga menunjukkan bahwa masingmasing variabel bebas memiliki nilai VIF $<10$ dan nilai toleransi (tolerance) $>0,1$

Maka dapat dikatakan bahwa regresi linier untuk faktor - faktor yang mempengaruhi pengeluaran pangan rumah tangga terbebas dari masalah multikolinieritas.

2. Uji asumsi heterokedastisitas

Uji heteroskedastisitas bertujuan untuk melihat apakah di dalam model regresi terjadi

ketidaksamaan varians dari residual satu pengamatan ke pengamatan lain dalam model regresi. Jika varians dari residual satu pengamatan ke pengamatan lain tetap, maka disebut homokedastisitas atau tidak terjadi heterokedastisitas. Model regresi yang baik adalah yang homokedastisitas atau tidak terjadi heterokedastisitas.

Metode grafik menunjukkan penyebaran titik- titik residual sebagai berikut:

a. Titik- titik data menyebar di atas dan di bawah atau di sekitar angka nol (0)

b. Titik data tidak mengumpul hanya di atas atau di bawah saja

c. Penyebaran titik- titik data tidak membentuk pola bergelombang menyebar kemudian menyempit danmelebar kembali

d. Penyebaran titik- titik tidak berpola.

Tabel 10. . Rata-rata pangsa pengeluaran pangan rumah tangga sampel di desa Karang Gading kecamatan Secanggang kabupaten Langkat

\begin{tabular}{lllll}
\hline No & Pangsa pengeluaran pangan & $\begin{array}{l}\text { Jumlah rumah tangga } \\
\text { sampel }\end{array}$ & $\begin{array}{l}\text { Persentase sampel } \\
(\%)\end{array}$ & $\begin{array}{l}\text { Rata-rata pangsa } \\
\text { pengeluaran pangan }(\%)\end{array}$ \\
\hline 1 & $\leq 60 \%$ & 33 & $35 \%$ & 54,62 \\
2 & $>60 \%$ & 61 & $65 \%$ & 69,44 \\
\hline & Rata-rata & & & 62,03
\end{tabular}

Sumber: data diolah dari lampiran 5

\section{Kesimpulan dan saran}

\subsection{Kesimpulan}

1. Faktor-faktor, secara serempak pendapatan keluarga, tingkat pendidikan ibu, jumlah anggota keluarga, dan umur perkawinan mempengaruhi pengeluaran pangan untuk konsumsi pangan rumah tangga. Secara parsial memiliki pengaruh yang nyata terhadap pengeluaran rumah tangga adalah: pendapatan rumah tangga dan jumlah anggota rumah tangga, sedangkan yang tidak memiliki pengaruh yang nyata/ signifikan terhadap pengeluaran rumah tangga adalah tingkat pendidikan ibu rumah tangga dan lamanya berumah tangga/ umur perkawinan.

2. Rumah tangga yang ada di Desa Karang Gading, Kecamatan Secanggang, Kabupaten Langkat termasuk rumah tangga tidak tahan pangan karena sebanyak $65 \%$ sampel rumah tangga memiliki besar pangsa atau persentase pengeluaran pangan yang tinggi.

\subsection{Saran}

1. Pangan merupakan kebutuhan yang paling mendasar bagai setiap individu oleh kerena itu, perhatian yang intensif sangat perlu dilaksanakan terkhusus bagi rumah tangga miskin.

2. Pemerintah diharapkan dapat memberikan stimulus bagi rumah tangga miskin d alam pencapaian katahanan pangan melalui pengendali jumlah anggota keluarga melalui penggalakan program KB pendataan yang dilakukan 
minimal satu tahun sekali untuk melihat kondisi masyarakat, sehingga pembagian beras raskin dapat lebih adil dan merata

3. Diharapkan kepada peneliti selanjutnya untuk dapat meneliti lebih lanjut tentang faktor-faktor untuk meningkatkan kesejahteraan masyarakat di daerah penelitian.

\section{References}

[1] Badan Ketahanan Pangan Kota Medan. 2010. Analisis dan Penyusunan Pola Konsumsi dan Supply Pangan Kota Medan. Medan

[2] Badan Pusat Statistik Kabupaten Langkat. 2015. Kecamatan Secanggan Dalam Angka. Medan

[3] Barus, Sepriyanti V. 2015. Analisis Faktor - Faktor yang Mempengaruhi Pengeluaran untuk Konsumsi Pangan Rumah Tangga Pasca

Erupsinya Gunung Sinabung di Desa Gajah, Kecamatan Simpang Empat, Kabupaten Karo. USU. Medan

[4] Deaton, A. and J. Muellbauer. 1980. Economics and Consumer Behavior. Cambridge University Press, London

[5] Fatimah,Empat.1995. Beberapa Faktor yang Mempengaruhi Alokasi Pengeluaran dan Tingkat Konsumsi Pangan Keluarga (Studi Kasus di Kelurahan Tanah Sareal, Bogor). Institut Pertanian Bogor. Bogor.

[6] Hardiansyah dan Suhardjo. 1987. Ekonomi Gizi. Diktat Jurusan Gizi Masyarakat dan Sumberdaya Keluarga. Fakultas Pertanian. IPB. Bogor.

[7] Hidayat,S.2005.Masalah Gizi di Indonesia, Kondisi Gizi Masyarakat Memprihatinkan. http :// www. suara pembaruan.online.

[8] Ilham, Nyak dan Bonar Sinaga. 2002. Penggunaan Pangsa Pengeluaran Pangan sebagai Indikator Komposit Ketahanan Pangan. IPB. Bogor.

[9] Mulyanto. 2005. Kemiskinan dan Kebutuhan Pokok. Rajawali. Jakarta.

[10] Munandir, H. 2002. Pembangunan Ekonomi di Dunia Ketiga. Erlangga. Jakarta

[11] Pracoyo, Kunawangsih, Try, Antyo Pracoyo. 2005. Aspek Dasar Ekonomi Makro di Indonesia. Grasindo. Jakarta.

[12] Purwaningsih, Yunastiti, Slamet Hartono, Masyhuri, Jangkung Handoyo Mulyo. 2010. Pola

[13] Pengeluaran Pangan Rumah Tangga Menurut Tingkat Ketahanan Pangan di Provinsi Jawa Tengah. Jurnal Ekonomi Pembangunan. Surakarta.

[14] Purwantini, dan Ariani. 2002. Pola Pengeluaran dan Konsumsi Pangan pada Rumah Tangga Petani Padi. Pusat Analisis Sosial Ekonomi dan Kebijakan Pertanian. Bogor.

[15] Purwantini, Tri., Handewi P. S. Rachman dan Yuni Marisa. 1999. Analisis Ketahanan Pangan Regional dan Tingkat Rumah Tangga. Pusat Analisis Sosial Ekonomi dan Kebijakan Pertanian. Institut Pertanian Bogor. Bogor.

[16] Rachman, Handewi, Mewa Ariani dan T.B. Purwantini. 2005. Distribusi Provinsi di Indonesia Menurut Derajat Ketahanan Pangan Rumah Tangga. Pusat Analisis Sosial Ekonomi dan Kebijakan Pertanian. Institut Pertanian Bogor.

[17] Rosida. 2007. Tingkat Pengeluaran Masyarakat. Kanisius. Yogyakarta.

[18] Simbolon, Friska Juliana. 2011. Analisis Faktor - Faktor yang Mempengaruhi Pengeluaran Pangan Rumah Tangga Miskin di Kecamatan Medan Tuntungan. USU. Medan

[19] Soekirman. 2000. Ilmu Gizi dan Aplikasinya Untuk Keluarga dan Masyarakat. Dirjen Pendidikan Tinggi Departemen Pendidikan Nasional. Jakarta.

[20] Suhardjo. 1989. Sosio Budaya Gizi. PAU Pangan dan Gizi. IPB. Bogor.

[21] Sumardi, M. 2003. Kemiskinan dan Kebutuhan Pokok. Rajawali Jakarta. Jakarta.

[22] Sumarmi, Sri. 2010. Ketahanan dan Kerawanan Pangan. Pelangi Gizi UNAIR. Surabaya.

[23] Suryana, Achmad. 2004. Kapita Selekta Ketahanan Pangan. BPFEYOGYAKARTA. Analisis dan Penghitungan Tingkat kemiskinan . BPS. Jakarta.

[24] Waluyo D.E. 2002. Teori Ekonomi Makro Edisi Revisi. UMM Press. Malang. 